\title{
PERANCANGAN SISTEM INFORMASI PENDAFTARAN DAN PEMBAYARAN RAWAT JALAN BERBASIS WEBSITE DI RUMAH SAKIT AMC BANDUNG
}

\author{
Ana Maesaroh \\ STKOM Al Ma'soem \\ anzmaesaroh@gmail.com \\ Topan Trianto \\ STKOM Al Ma'soem \\ Topant2018@gmail.com
}

\begin{abstract}
In the preparation of this thesis, the authors do research About Registration and Outpatient payment at RS AMC Bandung. According to the researchers, these activities have not been supported by a supportive system so that there are some obstacles such as the occurrence of registration queue, inefficient in serving outpatients. AMC Hospital as one of the public service institutions in the health sector requires the existence of an accurate, reliable, and sufficient information system to improve its services to patients and other related environments.

To overcome these problems, the authors designed an information system that can be used to facilitate the data processing of outpatients at the Hospital RS AMC, the method used in designing this system is the method RUP (Rational Unifed Process). RUP (Rational Unifed Process) is a software engineering method developed by collecting various best practices in the software mining industry, where the development tools use UML (Unified Modeling languange).

Thus, based on the system that has been created, it can facilitate the registration of patients who can be accessed anywhere, can improve information services for patients who will register and can expand the reach of information.
\end{abstract}

Keywords: Information System, Registration and Outpatient Payment, Website

\begin{abstract}
ABSTRAK
Dalam penyusunan tugas akhir ini, penulis melakukan penelitian Tentang Pendaftaran dan pembayaran Rawat jalan di RS AMC Bandung. Menurut penelitia, kegiatan tersebut belum ditunjang dengan sistem yang mendukung sehingga terjadi beberapa kendala seperti terjadinya antrian pendaftaran, tidak efisien dalam melayani pasien rawat jalan. Rumah Sakit AMC sebagai salah satu institusi pelayanan umum di bidang kesehatan membutuhkan keberadaan suatu sistem informasi yang akurat, handal, serta cukup memadai untuk meningkatkan pelayanannya kepada para pasien serta lingkungan yang terkaitlainnya.

Untuk mengatasi masalah tersebut, maka penulis merancang sebuah sistem informasi yang dapat digunakan untuk mempermudah dalam pengolahan data pasien rawat jalan di Rumah Sakit RS AMC, metode yang digunakan dalam merancang sistem ini ialah metode RUP ( Rational Unifed Process ). RUP (Rational Unifed Process) merupakan suatu metode rekayasa perangkat lunak yang dikembangkan dengan mengumpulkan berbagai best practises yang terdapat dalam industri pengambangan perangkat lunak, dimana alat pengembangannya menggunakan UML (Unified Modeling languange ).
\end{abstract}


Dengan demikian berdasarkan sistem yang telah dibuat, maka dapat mempermudah pendaftaran pasien yang dapat diakses dimanapun, dapat meningkatkan pelayanan informasi bagi pasien yang akan mendaftar dan dapat memperluas daya jangkau informasi.

Kata Kunci : Sistem Informasi, Pendaftaran dan Pembayaran Rawat Jalan, Website

\section{PENDAHULUAN}

\subsection{Latar Belakang Masalah}

Berkembangnya teknologi sistem informasi, maka penyajian informasi yang cepat dan efisien sangat dibutuhkan oleh setiap perusahaan. Perkembangan teknologi yang semakin pesat saat ini menuntut diubahnya pencatatan manual menjadi sistem yang terkomputerisasi. Demikian juga halnya pendaftaran pembayaran pasien pada suatu Rumah Sakit.

Dalam hal ini Rumah Sakit AMC sebagai salah satu pusat pelayanan kesehatan yang ada di Cileunyi, masih menggunakan Sistem semi komputerisasi sebagai pengendali sistem pendaftaran dan administrasi keuangan yang ada di rumah sakit ini. Hal ini menyebabkan ketidakefektifan dalam pelayanan kesehatan di rumah sakit ini, terutama bagi pasien rawat jalan. Dimana pasien harus datang langsung mengambil nomer antrian dan untuk kwitansi pembayaran masih menggunakan Microsoft Office Excel.

\subsection{Rumusan Masalah}

Dengan sistem yang berjalan di Rumah Sakit AMC, terdapat kendala-kendala yang dihadapi diantaranya:

1. Penumpukan antrian

2. Terjadinya kesalahan penginputan data pasien

3. Terjadinya duplikasi data

4. Hilangnya data pasien

5. Petugas kesulitan dalam mencari data pasien

6. Kesalahan dalam perhitungan biaya berobat

7. Kesulitan dalam membuat laporan.

\subsection{Batasan Masalah}

Batasan masalah Sistem Informasi Pendaftaran dan Administrasi Keuangan Instalasi Rawat Jalan Rumah Sakit AMC Bandung meliputi:

1. Sistem Pendaftaran On-line

2. Sistem Pembayaran Biaya Berobat

\subsection{Maksud dan Tujuan Penelitian}

Maksud dari pembuatan Tugas Akhir ini ialah untuk membuat suatu Sistem Informasi Pendaftaran dan Pembayaran Rawat Jalan di Rumah Sakit AMC. Adapun tujuan dari pembuatan sistem ini diantaranya :

1. Mengurangi penumpukan antrian

2. Memperkecil terjadinya kesalahan penginputan data pasien

3. Adanya validasi data

4. Keamanan data pasien terjamin

5. Mempermudah petugas dalam mencari data pasien

6. Memperkecil kesalahan dalam perhitungan biaya berobat

7. Mempermudah dalam membuat laporan.

\subsection{Kegunaan Penelitian}


Kegunaan Penelitian dari penyusunan Tugas Akhir ini adalah :

1. Bagi Rumah Sakit AMC dapat mempermudah pasien dalam pengambilan nomor dan proses daftar,sehingga tidak terjadi antrian panjang untuk mendapatkan nomor, untuk petugas pendaftaran dapat mempermudah penginputan data pasien, dan untuk petugas kasir dapat mempermudah dalam perhitungan biaya berobat pasien secara cepat danefisien.

2. Bagi AMIK Al Ma'soem merupakan masukan dalam pengembangan kurikulum yang berjalan.

3. Bagi penulis dapat memperluas pengetahuan mengenai sistem informasi pendaftaran dan pembayaran rawat jalan di RS AMC Bandung, serta dapat lebih memahami proses pembuatan sistem yangdibuat.

4. Bagi pembaca dapat menambah wawasan tentang sistem informasi yangdibuat.

\section{METODOLOGI}

\subsection{Metode Penelitian}

Metode yang digunakan dalam penelitian ini yaitu metode deskriptif. Metode deskriptif adalah metode penelitian yang berusaha menggambarkan objek yang diteliti sesuai dengan apa adanya, dengan tujuan menggambarkan secara sistematis, fakta dan karakteristik objek yang diteliti secara tepat. Metode penelitian yang digunakan dalam pengumpulan data diperoleh dengan cara:

1. Tinjauan Lapangan

Tinjauan lapangan yang dilakukan untuk memperoleh data sebagai analisa terdapat 2 (dua) cara, yaitu:

a. Observasi/Pengamatan

Kegiatan ini dilakukan dengan mengamati secara langsung yang berhubungan dengan sistem pendaftaran dan pembayaran rawat jalan yang akan digunakan sebagai masukan Tugas Akhir ini.

b. Wawancara

Wawancara ini digunakan untuk mengajukan pertanyaan lisan dalam mendapatkan dan melengkapi data yang diperoleh dengan wawancara kepada bagian terkait.

2. Studi Pustaka

Penelitian dilakukan dengan memperoleh data dan mempelajaribuku- buku, diktat kuliah yang berkaitan dengan metode Tugas Akhir baik dari perpustakaan AMIK Al-Ma'soem maupun internet dan bahan-bahan lainnya yang erat kaitannya dengan informasi mengenai Sistem Informasi pendaftaran dan pembayaran rawat jalan.

3. Studi Dokumentasi

Metode pengumpulan data dengan cara membaca data dan mencatatnya dari dokumen atau catatan-catatan yang berhubungan dengan pendaftaran dan pembayaran di RS AMC.

\subsection{Metode PengembanganSistem}

Metode yang digunakan dalam merancang sistem ini ialah metode RUP ( Rational Unifed Process ). RUP (Rational Unifed Process) merupakan suatu metode rekayasa perangkat lunak yang dikembangkan dengan mengumpulkan berbagai best practises yang terdapat dalam industri pengambangan perangkat lunak. dimana alat pengembangannya menggunakan UML (Unified Modeling languange).

\section{ANALISA DAN PERANCANGAN SISTEM}

3.1 Deskripsi Prosedur Kerja 
Dibawah ini merupakan prosedur kerja dari sistem informasi rawat jalan di Rumah Sakit Umum Pindad :

1. Bagi Pasien Baru datang ke RS dengan membawa kartu identitas diri berupa KTP untuk kemudian diserahkan kepada petugas.

2. Bagi Pasien Lama membawa Kartu Tanda Berobat (KTB) untuk kemudian diserahkan kepada petugas.

3. Petugas mengentry data pasien untuk kemudian membuatkan kartu tanda berobat (KTB) dan Kartu Bukti Daftar untuk diberikan kepada pasien baru. Pasien lama cukup Kartu Bukti Daftar.

4. Petugas membuat Laporan Kunjungan Pasien untuk diserahkan kepada Direktur.

5. Dokter memeriksa keadaan pasien berdasarkan KTB untuk kemudian memberikan hasil diagnosa dan resep kepada petugas.

6. Petugas mengentry diagnosa untuk kemudian apabila memerlukan riwayat penyakit pasien.

7. Pasien membawa resep ke bagian petugas farmasi untuk kemudian di berikan obat.

8. Petugas Farmasi mengentry resep obat dan memberikan resi obat yang belum ditebus kepada pasien.

9. Petugas Farmasi membuat Laporan Penjualan Obat untuk diserahkan kepada Direktur.

10. Pasien membawa resi obat ke petugas Kassa untuk kemudian dilakukan pembayaran terlebih dahulu.

11. Petugas Kassa mengentry data resi obat dan memberikan kwitansi pembayaran kepada pasien.

12. Pasien Kembali ke petugas farmasi dengan membawa bukti pembayaran untuk menebus obat.

13. Selesai.

\subsection{Proses Bussines Object Model}

Proses bisnis digambarkan dengan bisnis use case model, yang menggambarkan interaksi bisnis aktor dengan sistem, seorang atau sebuah aktor adalah sebuah entitas atau mesin yang berinteraksi dengan sistem untuk melakukan pekerjaan tertentu.

\subsection{Use Case Bisnis}

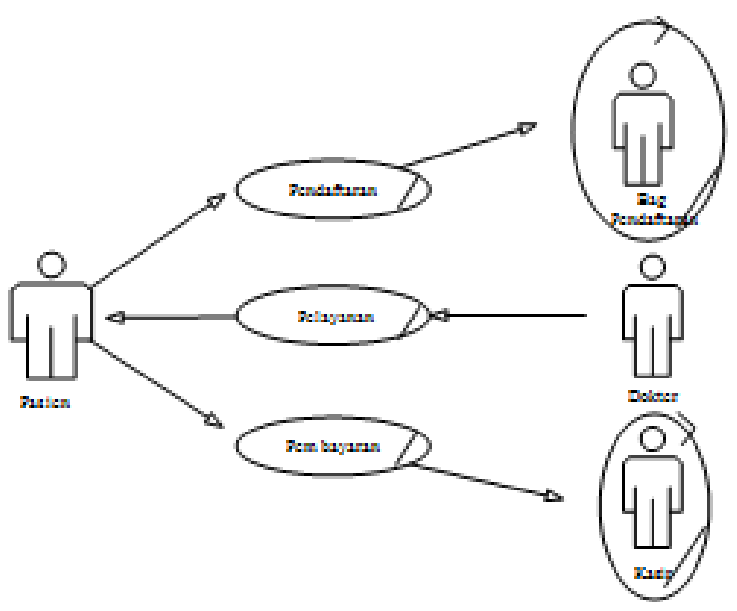

Gambar 1 Bisnis Use Case Bisnis

\subsection{Deskripsi Dokumen}

Deskripsi dokumen-dokumen yang ada di Rumah Sakit AMC yaitu : 
1. Kartu Tanda Berobat (KTB)

Fungsi : Menginformasikan data pasien.

Sumber : Petugas

Distribusi : Pasien dan Dokter

Rangkap :1(Satu)

Frekuensi : Setiap transaksi pendaftaran pemeriksaan pasien :

IsiDokumen :

Tabel 1 Struktur Kartu Tanda Berobat

\begin{tabular}{|c|l|l|}
\hline No & \multicolumn{1}{|c|}{ Nama } & \multicolumn{1}{|c|}{ Keterangan } \\
\hline 1. & RekamMedis & Nomor Rekam Medis \\
\hline 2. & NamaPasien & Nama Pasien \\
\hline 3. & Jenis Kelamin & Jenis Kelamin Pasien \\
\hline 4. & TempatLahir & Tempat Lahir Pasien \\
\hline 5. & Tanggal Lahir & Tanggal Lahir Pasien \\
\hline 6. & Telp & Telepon Pasien \\
\hline
\end{tabular}

2. Pendaftaran

$\begin{array}{ll}\text { Fungsi } & \text { : Menginformasikan Bukti Pendaftaran } \\ \text { Sumber } & \text { : Petugas } \\ \text { Distribusi } & : \text { Pasien dan Dokter } \\ \text { Rangkap } & : \text { 1(Satu) } \\ \text { Frekuensi } & : \text { Setiap pemeriksaan pasien } \\ \text { IsiDokumen } & :\end{array}$

Tabel 2 Struktur Bukti Pendaftaran

\begin{tabular}{|c|l|l|}
\hline No & \multicolumn{1}{|c|}{ Nama } & \multicolumn{1}{c|}{ Keterangan } \\
\hline 1. & RekamMedis & Nomor Rekam Medis \\
\hline 2. & NamaPasien & Nama Pasien \\
\hline 3. & Jenis Kelamin & Jenis Kelamin Pasien \\
\hline 4. & TempatLahir & Tempat Lahir Pasien \\
\hline 5. & Usia & Usia Pasien \\
\hline 6. & Poliklinik & Poli yang dituju pasien \\
\hline 7. & No.Antri & Nomor Antrian Pasien \\
\hline 8. & Tanggal Daftar & Tanggal Daftar Pasien \\
\hline
\end{tabular}

\subsection{Identifikasi Kebutuhan Pemakai}

Dalam mengidentifikasi kebutuhan pemakai harus disesuaikan dengan keadaan yang ada di Rumah Sakit Umum Pindad, antara lain:

1. Sistem yang dirancang dapat mempermudah dalam pemberian informasi bagi pemakai.

2. Sistem yang dirancang dapat membantu kegiatan operasional Rumah Sakit.

3. Sistem yang dibuat harus memiliki sistem pengamanan data yaitu dengan menggunakan password, agar sistem tidak dapat dioperasikan oleh sembarangan orang.

4. Sistem yang dibuat harus dapat menyimpan data dengan baik, rapih dan aman.

\subsection{Analisa Kebutuhan Sistem}

Menjelaskan kondisi atau kemampuan yang harus dipenuhi oleh sistem sesuai dengan spesifikasi yang diinginkan oleh pemakai, meliputi kebutuhan informasi, kebutuhan aplikasi untuk menghasilkan informasi tersebut dan kebutuhan perangkat keras. Analisa kebutuhan sistem terdiri dari :

1. Kebutuhan Informasi

Sistem informasi rawat jalan di Rumah Sakit Umum Pindad harus mampu menghasilkan 
informasi yang cepat, tepat dan akurat karena informasi yang dihasilkan dapat dipergunakan sebagai bahan pertimbangan dalam pengambilan keputusan. Adapun informasi yang dibutuhkan dalam sistem ini antara lain sebagai berikut :

Tabel 3 Kebutuhan Informasi

\begin{tabular}{|c|c|c|c|}
\hline No & Nama & Tujuan & Frekuensi \\
\hline 1. & $\begin{array}{c}\text { Kwitansi } \\
\text { Pembayaran }\end{array}$ & Pasien & $\begin{array}{c}\text { Setiap } \\
\text { transaksi } \\
\text { pembayaran }\end{array}$ \\
\hline 2. & $\begin{array}{c}\text { Kartu Rekam } \\
\text { Medis }\end{array}$ & $\begin{array}{c}\text { Dokter/Pasien/ } \\
\text { Pihak RS }\end{array}$ & $\begin{array}{c}\text { Jika } \\
\text { Diperlukan }\end{array}$ \\
\hline 3. & $\begin{array}{c}\text { Laporan } \\
\text { Pendaftaran }\end{array}$ & Direktur & Setiap hari \\
\hline 4. & $\begin{array}{c}\text { Laporan } \\
\text { Pembayaran }\end{array}$ & Direktur & Setiap hari \\
\hline
\end{tabular}

2. Kebutuhan Aplikasi

Kebutuhan aplikasi dalam perancangan sistem informasi rawat jalan di Rumah Sakit AMC yaitu terdiri dari pengolahan data master dan transaksi. Pengolahan data master meliputi pengolahan data pasien, user, data dokter, data obat, data diagnosa dan data poliklinik. Adapun pengolahan transaksi yang meliputi transaksi pendaftaran, rekam medis, farmasi serta pembayaran.

\subsection{Analisis Kebutuhan Perangkat Lunak}

Perangkat lunak merupakan program komputer yang berfungsi sebagai sarana interaksi antara pengguna dengan perangkat keras komputer. Perangkat lunak juga dapat dijadikan sebagai penerjemah perintah-perintah yang dijalankan oleh pengguna komputer untuk kemudian diproses oleh perangkat keras komputer. Analisa kebutuhan perangkat lunak terdiri dari :

1. Use Case Diagram

a. Use Case Diagram Pasien

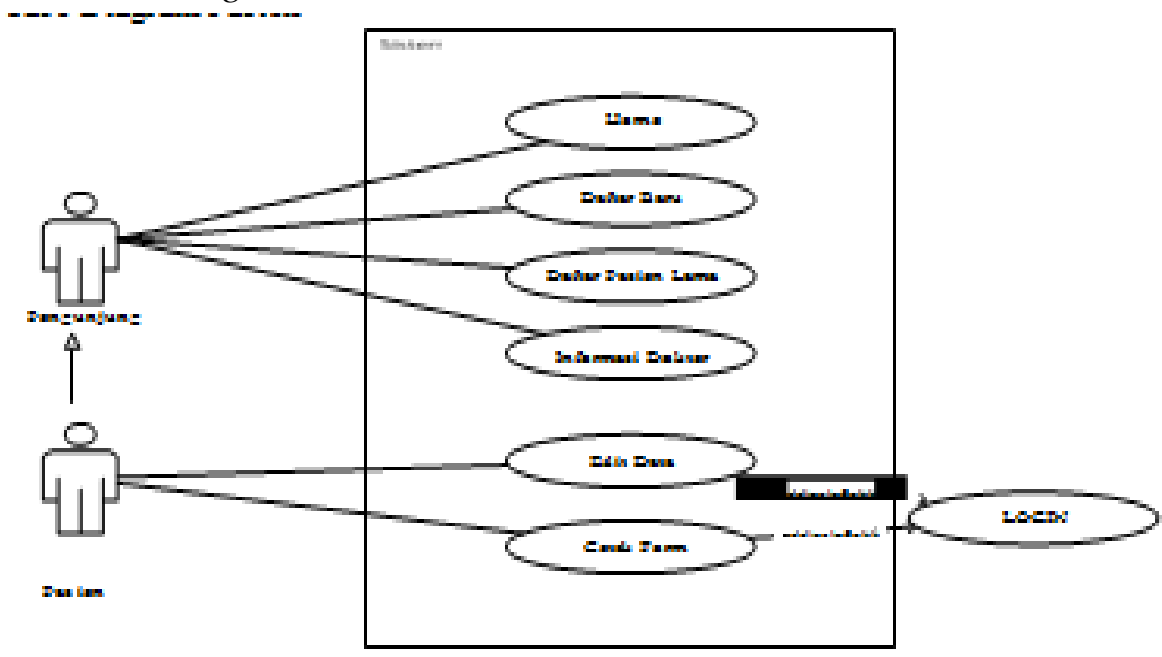

Gambar 3 Bisnis Use Case Diagram Pasien 


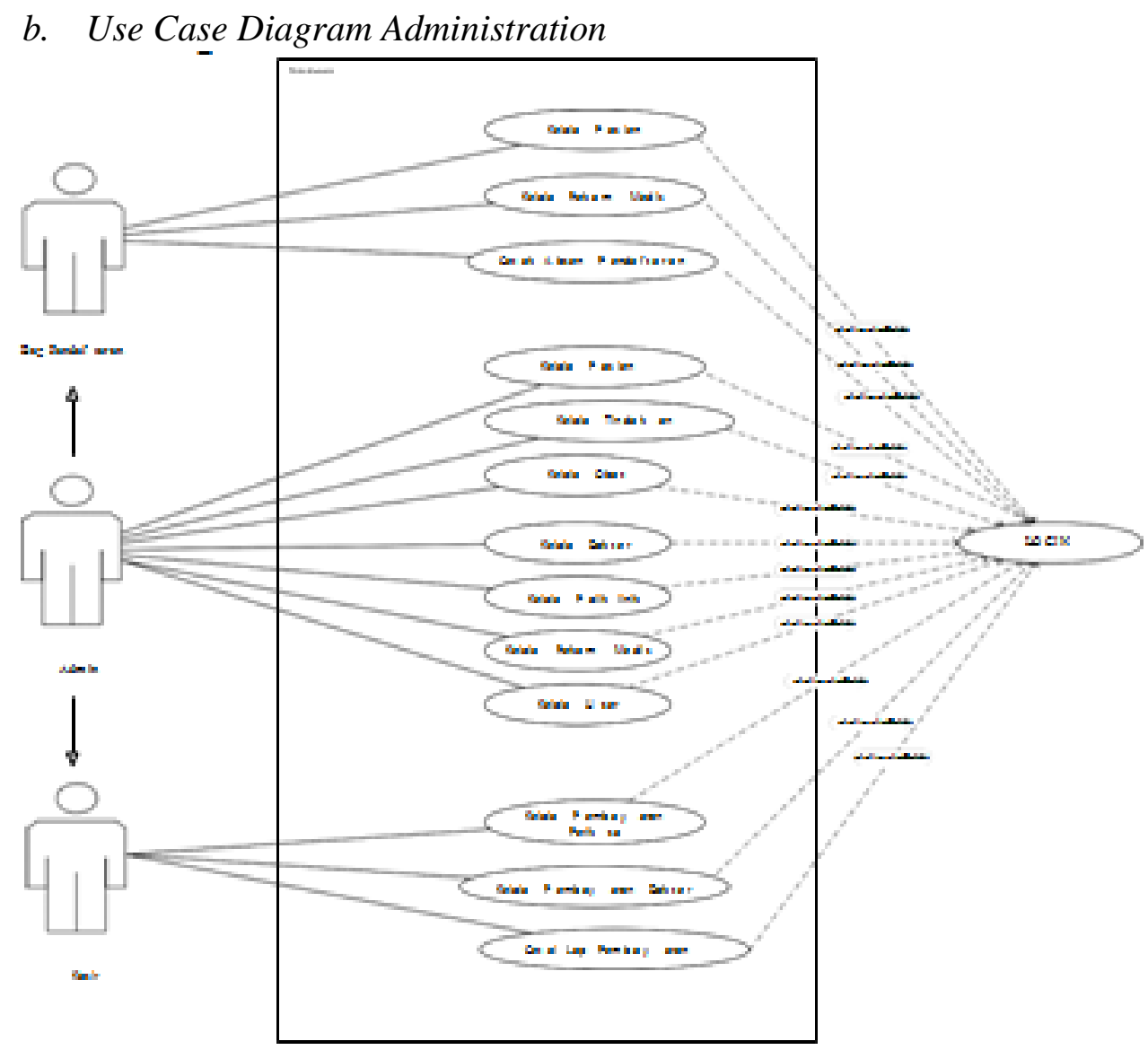

Gambar 3 Bisnis Use Case Diagram Administration

2. Flow of Event (Skenario)

Skenario merupakan penjelasan lebih detail dari kasus (case) dari awal hingga akhirnya diperoleh sebuah output. Yang termasuk flow of event adalah :

a. Flow of Event (Skenario) Pengunjung

Tabel 4 Flow of Event Pengunjung 1

\begin{tabular}{|l|l|}
\hline \multicolumn{2}{|c|}{ Identifikasi } \\
\hline No. use case & P 1 \\
\hline Nama use case & Home \\
\hline Deskripsi & Menampilkan halaman Home \\
\hline Aktor & Pengunjung \\
\hline \multicolumn{2}{|c|}{ Skenario Utama } \\
\hline Kondisi Awal & Halaman Home telah ditampilkan \\
\hline Aksi Aktor & Respon Sistem \\
\hline Klik Home & $\begin{array}{l}\text { Sistem meload halaman Home } \\
\text { Sistem menampilkan halaman Home }\end{array}$ \\
\hline Kondisi Akhir & Halaman Home ditampilkan \\
\hline
\end{tabular}


Tabel 5 Flow of Event Pasien 1

\begin{tabular}{|l|l|}
\hline \multicolumn{2}{|c|}{ Identifikasi } \\
\hline No. use case & P 2 \\
\hline Nama use case & Home \\
\hline Deskripsi & Menampilkan halaman Home \\
\hline Aktor & Pasien \\
\hline \multicolumn{2}{|c|}{} \\
\hline Kondisi Awal & $\begin{array}{c}\text { Skenario } \\
\text { Utama }\end{array}$ \\
\hline Aksi Aktor & Respon Sistem \\
\hline Klik Home & $\begin{array}{l}\text { Sistem meload halaman Home } \\
\text { Sistem menampilkan halaman Home }\end{array}$ \\
\hline Kondisi Akhir & Halaman Home ditampilkan \\
\hline
\end{tabular}

c. Flow of Event (Skrenario) Administrator

Tabel 6 Flow of Event Admin 1

\begin{tabular}{|l|l|}
\hline \multicolumn{2}{|c|}{ Identifikasi } \\
\hline No. use case & ADM 1 \\
\hline Nama use case & Kelola Pasien \\
\hline Deskripsi & Menampilkan halaman kelola pasien \\
\hline Aktor & Admin \\
\hline \multicolumn{2}{|c|}{ Skenario Utama } \\
\hline Kondisi Awal & Halaman kelola pasien telah ditampilkan \\
\hline Aksi Aktor & Respon Sistem \\
\hline $\begin{array}{l}\text { Klik submenu } \\
\text { kelola }\end{array}$ & $\begin{array}{l}\text { Sistem meload halaman Kelola Pasien } \\
\text { Sistem menampilkan halaman kelola pasien }\end{array}$ \\
\hline Input data & Menyimpan data pasien \\
\hline Kondisi Akhir & Halaman Kelola ditampilkan \\
\hline
\end{tabular}

d. Flow of Event (Skrenario) bag Pendaftaran

Tabel 7 Flow of Event Pendaftaran 1

\begin{tabular}{|c|c|}
\hline \multicolumn{2}{|r|}{ Identifikasi } \\
\hline No. use case & PD 1 \\
\hline Nama use case & Kelola Pasien \\
\hline Deskripsi & Menampilkan halaman kelola pasien \\
\hline Aktor & Bag pendaftran \\
\hline \multicolumn{2}{|r|}{ Skenario Utama } \\
\hline Kondisi Awal & Halaman kelola pasien telah ditampilkan \\
\hline Aksi Aktor & Respon Sistem \\
\hline $\begin{array}{l}\text { Klik submenu } \\
\text { kelola }\end{array}$ & $\begin{array}{l}\text { 1.Sistem meload halaman Kelola Pasien } \\
\text { 2.Sistem menampilkan halaman kelola pasien }\end{array}$ \\
\hline Input data & Menyimpan data pasien \\
\hline Kondisi Akhir & Halaman Kelola ditampilkan \\
\hline
\end{tabular}


e. Flow of Event (Skrenario) Bagian Kasir

Tabel 8 Flow of Event kasir 1

\begin{tabular}{|l|l|}
\hline \multicolumn{2}{|c|}{ Identifikasi } \\
\hline No. use case & K1 \\
\hline Nama use case & Kelola Pembayaran \\
\hline Deskripsi & Menampilkan halaman kelola pembayaran \\
\hline Aktor & Kasir \\
\hline \multicolumn{2}{|c|}{ Skenario Utama } \\
\hline Kondisi Awal & Halaman kelola pembayaran telah ditampilkan \\
\hline Aksi Aktor & Respon Sistem \\
\hline $\begin{array}{l}\text { Klik submenu } \\
\text { kelola }\end{array}$ & $\begin{array}{l}\text { 1.Sistem meload halaman Kelola pembayaran } \\
\text { 2.Sistem menampilkan halaman kelola pembayaran }\end{array}$ \\
\hline Input data & Menyimpan data pembayaran \\
\hline Kondisi Akhir & Halaman Kelola ditampilkan \\
\hline
\end{tabular}

3. Activity Diagram

Activity Diagram berguna untuk menggambarkan aliran fungsional dalam sebuah sistem.

Activity Diagram terdiri dari :

a. Activity Diagram Pasien

i) Activity Diagram Informasi Edit Data

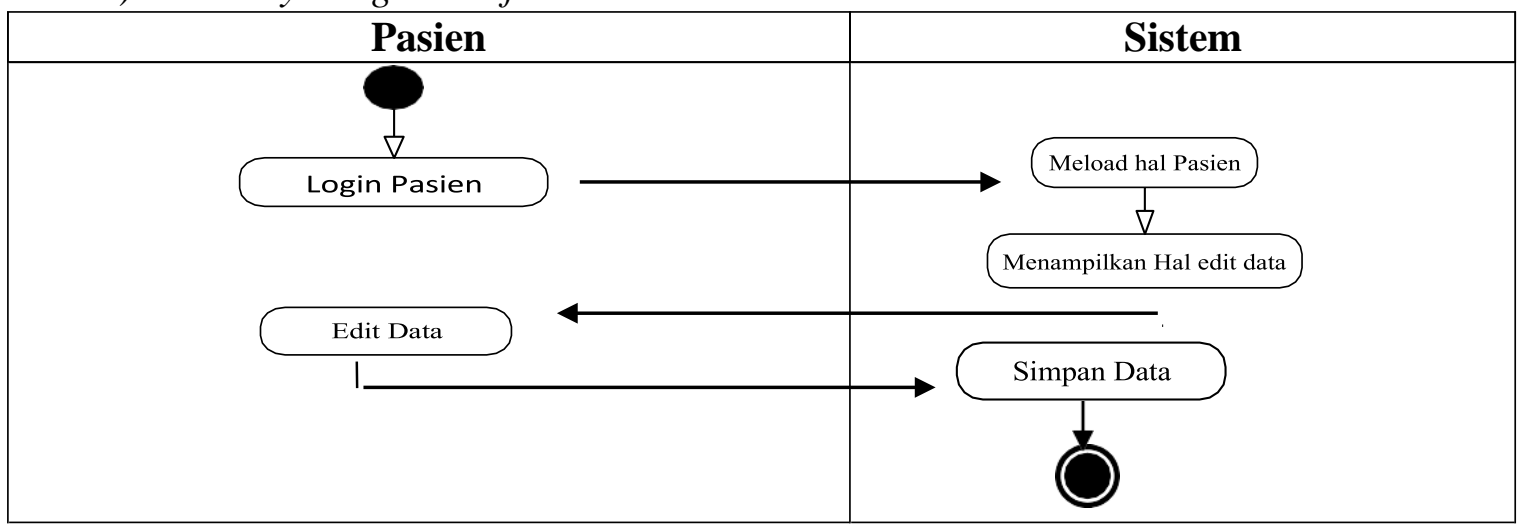

Gambar 4 Activity Diagram Edit Data

b. Activity DiagramAdministrator

i) Activity Diagram Home Admin

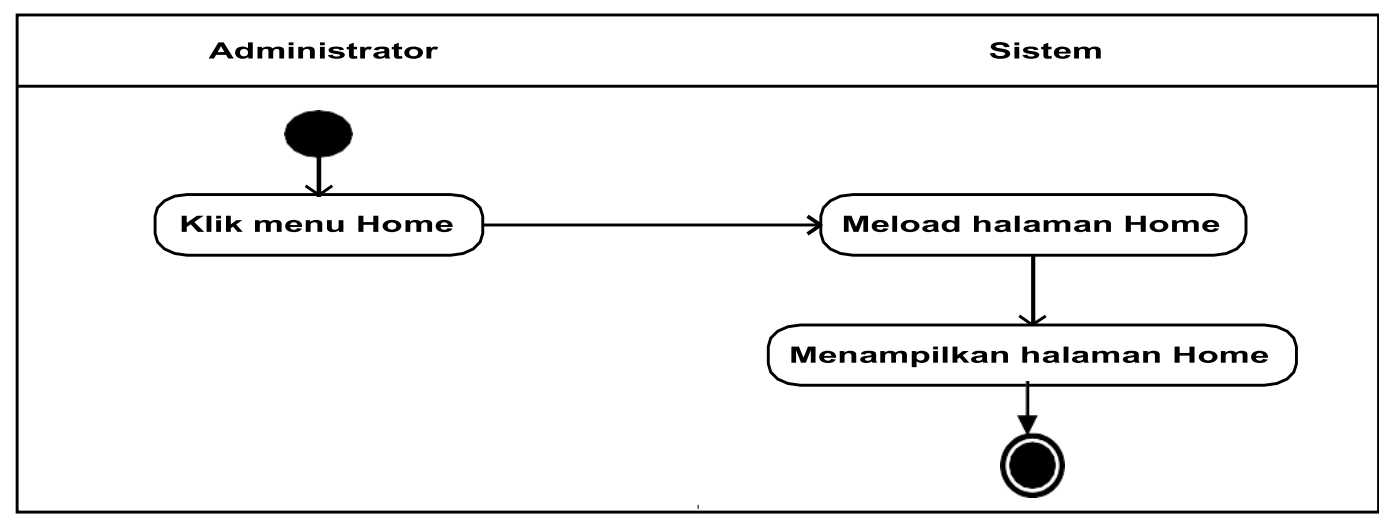

Gambar 5 Activity Diagram Home Admin 
c. Activity Diagram Pendaftaran

i) Activity Diagram Kelola Pasien

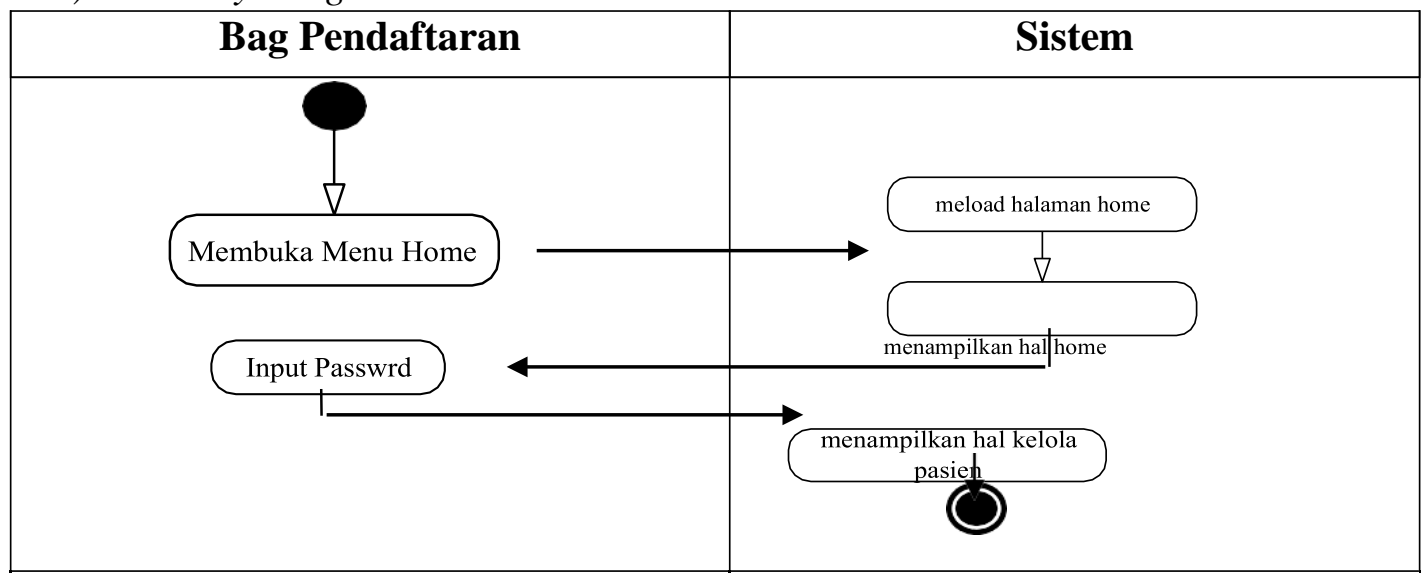

Gambar 6 Activity Diagram Kelola Pasien

\subsection{Sequence Diagram}

Sequence Diagram merupakan diagram untuk menggambarkan perilaku sistem terhadap suatu interaksi antar kelas berdasarkan urutan waktu. Sequence Diagram terdiri dari:

1. Sequence Diagram Pasien

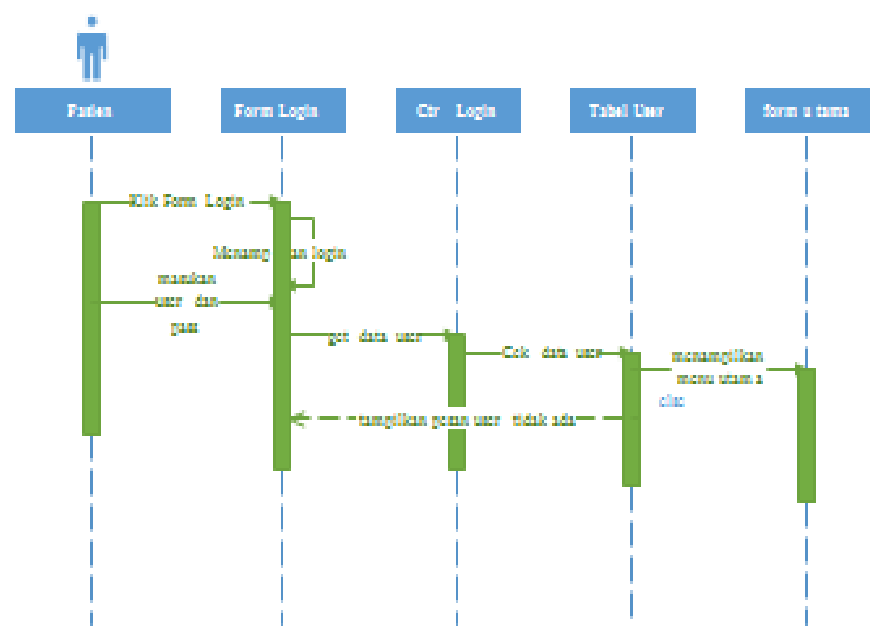

Gambar 7 Sequence Diagram Pasien 
2. Sequence Diagram Pendaftaran

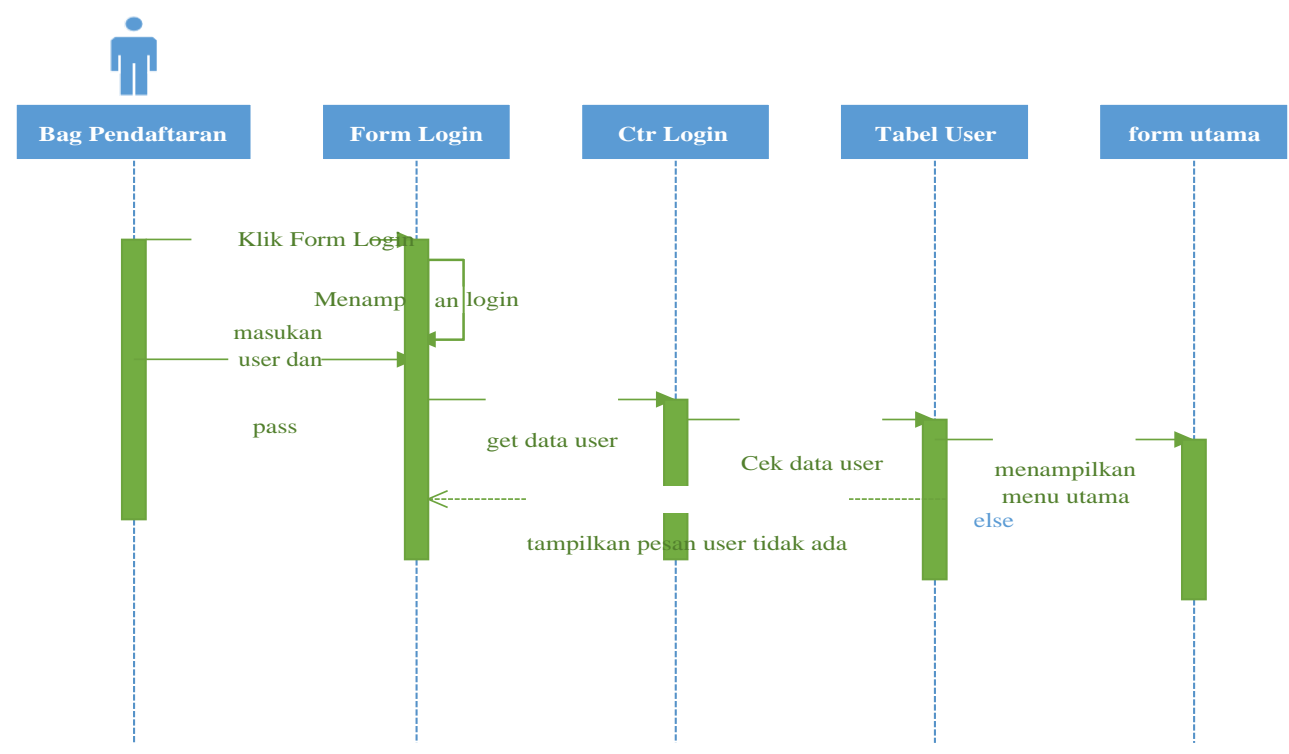

Gambar 8 Sequence Diagram Pendaftaran

3. Sequence Diagram Kasir

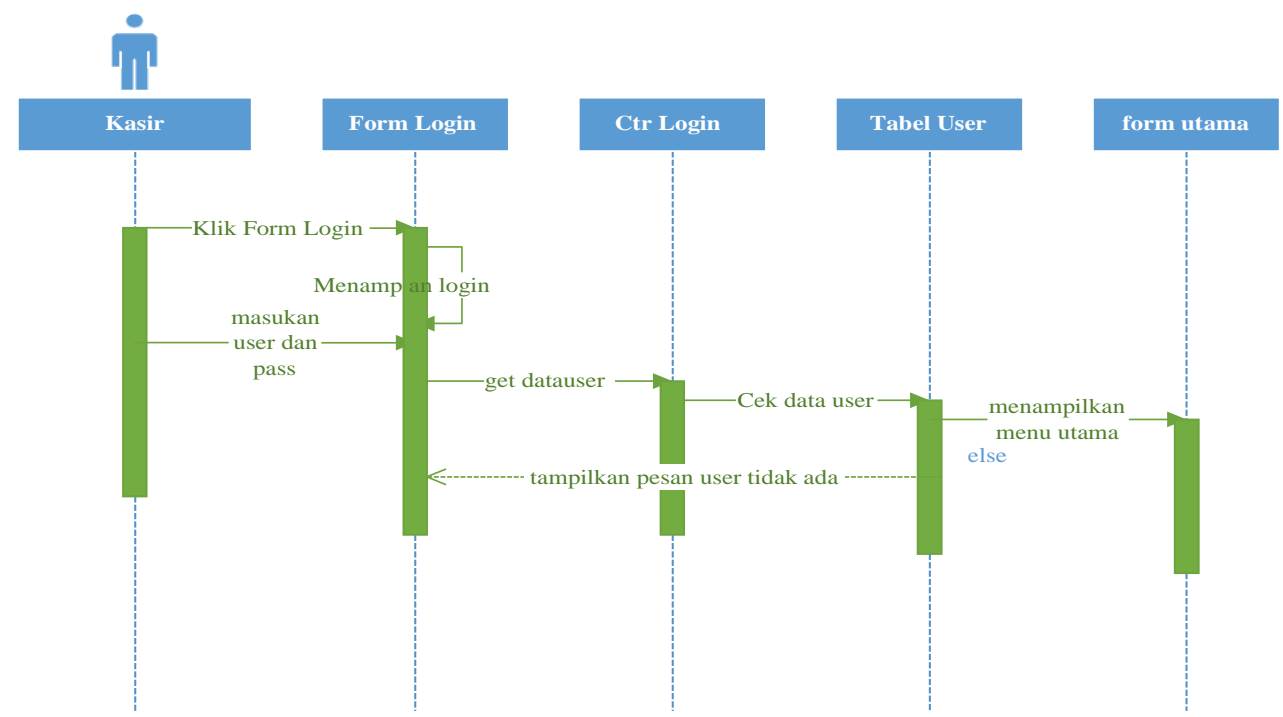

Gambar 9 Sequence Diagram Kasir 
4. Sequence Diagram Admin

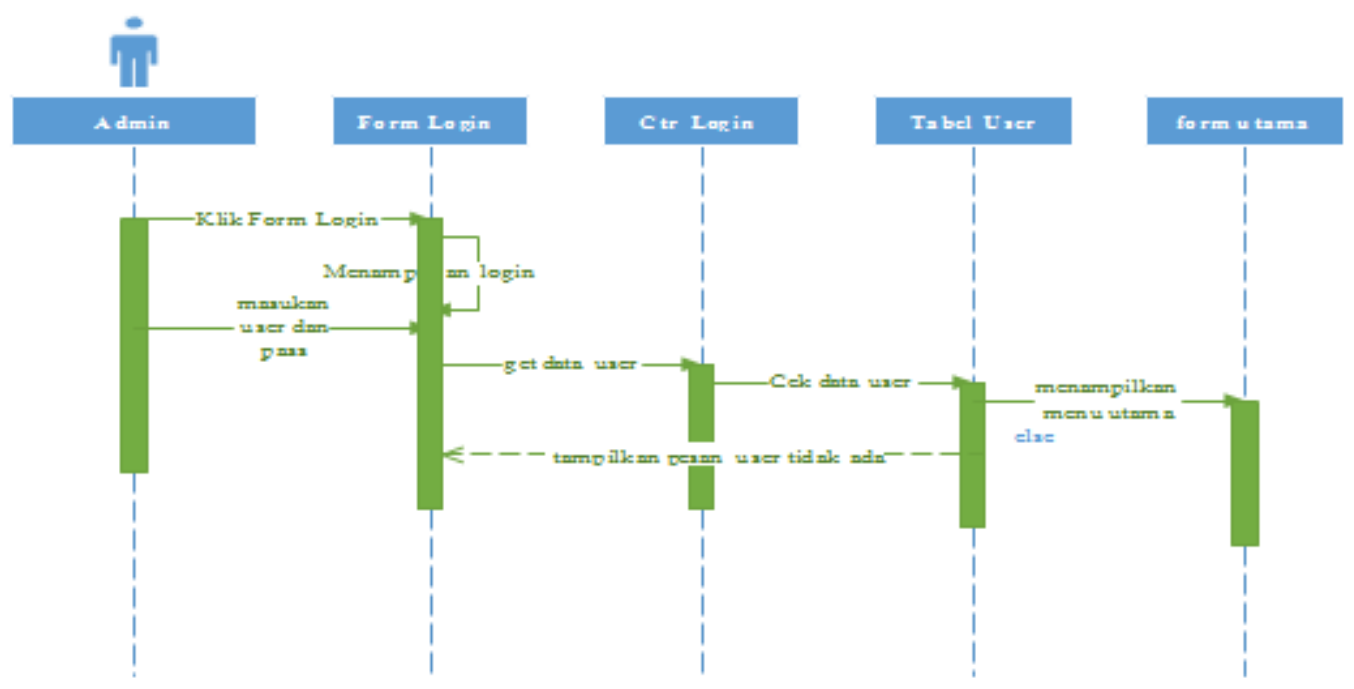

Gambar 10 Sequence Diagram Admin

\subsection{Class Diagram}

Class Diagram menggambarkan struktur statis class di dalam sistem, class mempresentasikan sesuatu yang ditangani oleh sistem. Class Diagram adalah dekripsi kelompok obyek-obyek dengan properti, perilaku (operasi) dan relasi yang sama. Class Diagram sangat membantu dalam visualisasi struktur kelas dari suatu sistem untuk memberikan pandangan global atas sebuah sistem. Sebuah sistem biasanya mempunyai beberapa class Diagram. Berikut ini adalah Class Diagram Sistem Informasi pendaftaran dan pembayaran di RS AMC.

1. Class Diagram Pasien

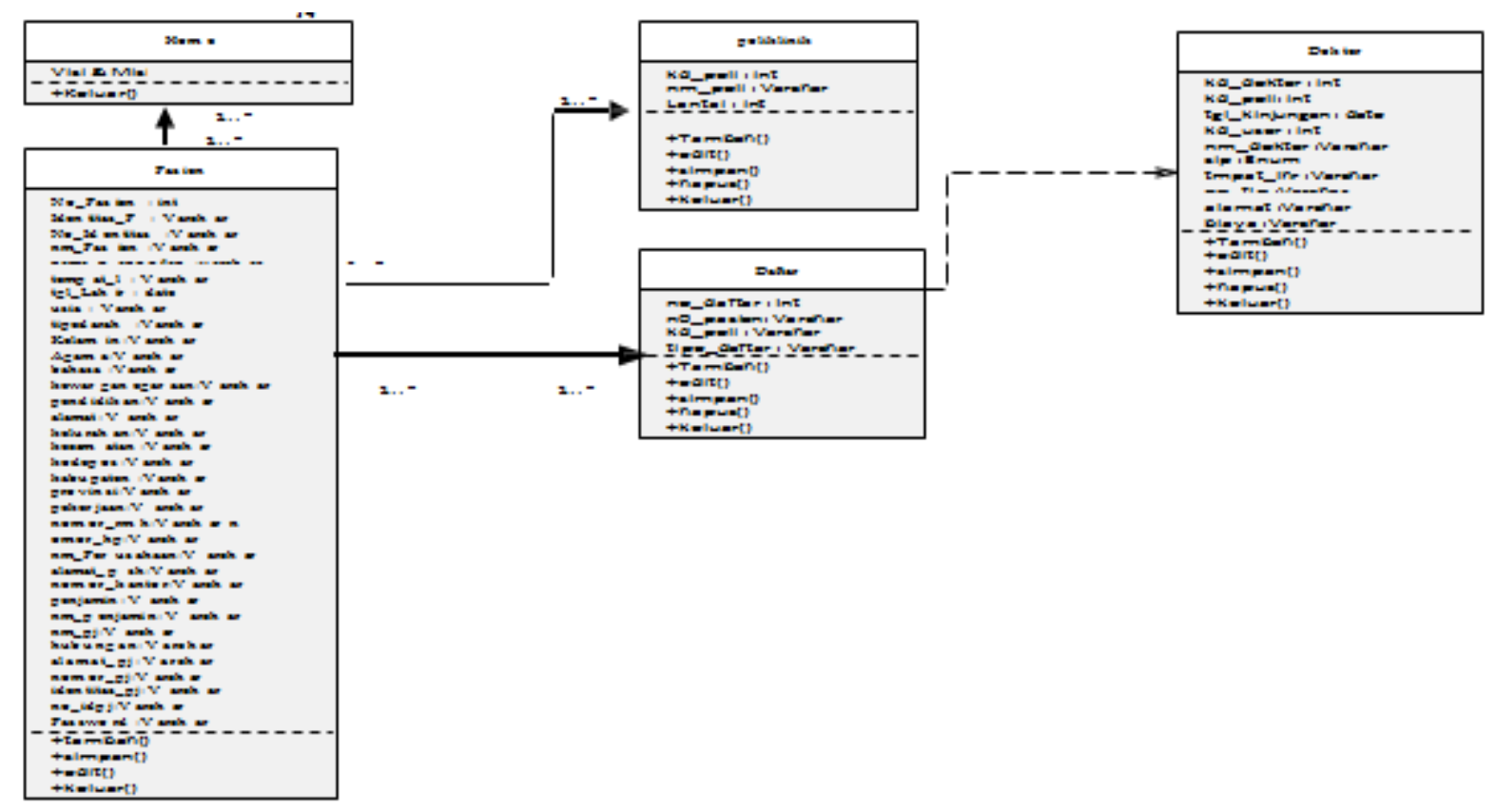

Gambar 11 Class Diagram Pasien 


\subsection{Antarmuka Pemakai} administrator.

Berikut ini adalah perancangan antar muka pemakai antara pengunjung dan

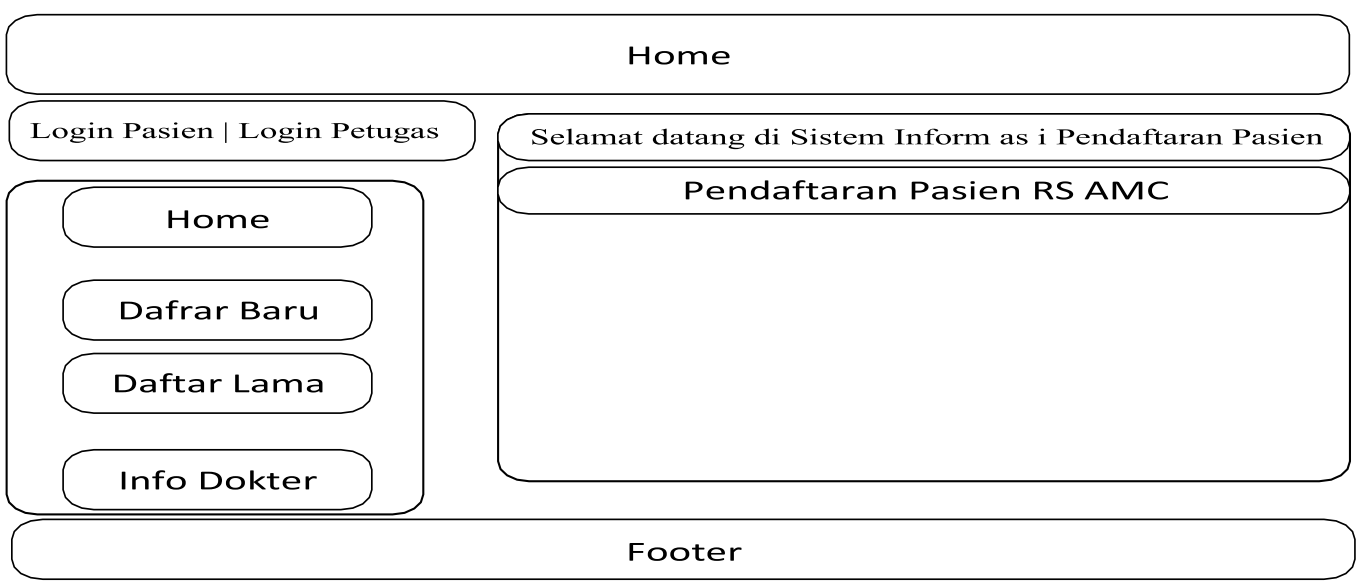

Gambar 12 Tata Letak Layar Pengunjung

\subsection{Perancangan Perangkat Keras}

Pada bagian ini menjelaskan hasil perancangan perangkat keras misalnya konfigurasi spesifikasi perangkat keras (hardware) dan spesifikasi perangkat lunak (software). Perancangan perangkat keras menjelaskan spesifikasi perangkat keras yang akan digunakan oleh sistem yang akan dibangun dengan disertai penjelasan kebutuhan untuk spesifikasi perangkat lunak sistemnya. Perancangan perangkat keras terdiri dari :

1. Kofigurasi Perangkat Keras

Konfigurasi perangkat keras merupakan gambaran struktur dan hubungan antar komponen dari sistem keseluruhan secara fisik.

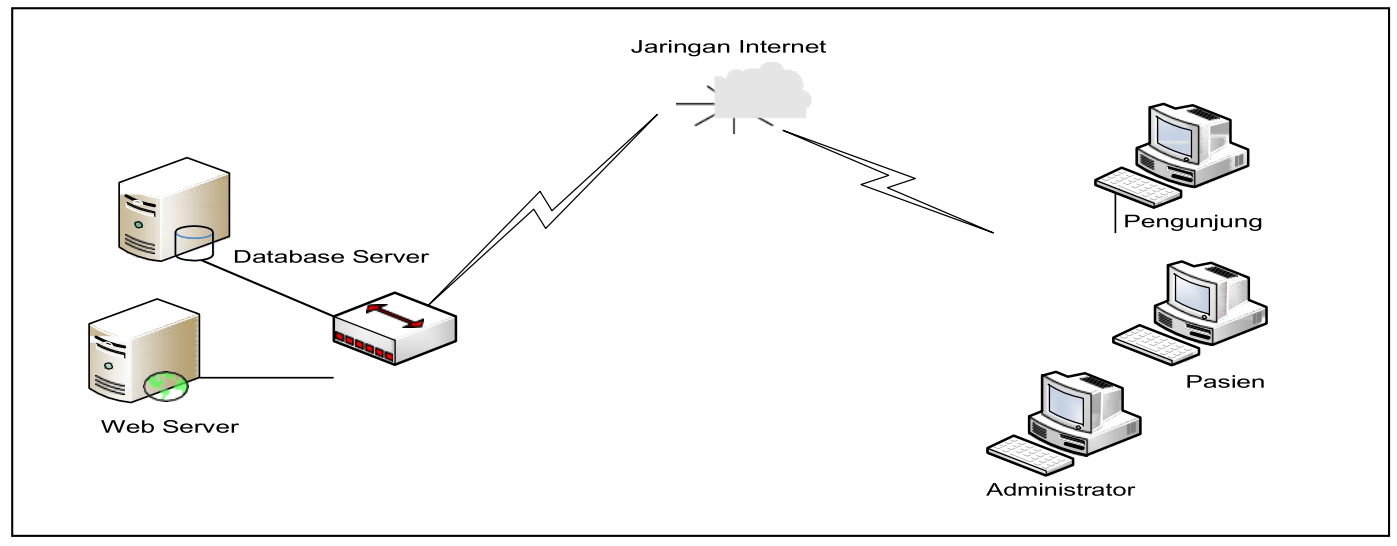

Gambar 13 Konfigurasi Perangkat Keras

2. Spesifikasi Perangkat Keras Spesifikasi perangkat keras (hardware) minimum yang digunakan user untuk dapat menjalankan sistem ini yaitu :
a. Processor Intel $®$ Core $®$ Dual CPU
b. Memory (RAM) 256MB
c. Harddisk 80GB
d. VGA Card $32 \mathrm{MB}$ On board 

e. Monitor 12 inc
f. Keyboard USB
g. Mouse USB
h. Optical Drive DVD 12X
i. Modem ADSL Standar

3. Spesifikasi Perangkat Lunak

Spesifikasi perangkat lunak (software) untuk dapat menjalankan sistem ini yaitu sebagai berikut :
a. Browser seperti Internet Explorer, Mozilla Firefox, Opera atau yang setara dengannya.
b. Sistem Operasi Windows.
c. Dream weaver CS4, sebagai editor code dan layout.
d. Xampp sebagai web server aplikasi.
e. Php My Admin untuk databasenya.

\section{PENUTUP}

\subsection{Kesimpulan}

Berdasarkan sistem yang telah dibuat, maka dapat disimpulkan beberapa hal, yaitu:

1. Dapat mempermudah pendaftaran pasien yang dapat diakses dimana pun.

2. Dapat meningkatkan pelayanan informasi bagi pasien yang akan mendaftar dan tidak terbatas pada jamkerja

3. Dapat memperluas daya jangkau informasi

\subsection{Saran}

Dalam perancangan website ini, masih banyak kekurangan. Oleh karena itu, penulis memberikan saran-saran sebagai berikut :

1. Website ini tidak hanya dijadikan media pembelajaran, tapi kedepannya dapat dijadikan sebagai media promosi Rumah Sakit AMC.

2. Sebelum sistem ini diimplemetasikan di perusahhan ada baiknya dilakukan pelatihan terhadap operator demi kelancaran penggunaan sistem.

\section{DAFTAR PUSTAKA}

Al Fatta, Hanif. (2007). Analisis dan Perancangan Sistem Informasi untuk Keunggulan Bersaing Perusahaan dan Organisasi Modern. Yogyakarta : Andi.

Arifin, Johar. (2005). Aplikasi Excel untuk perencanaan bisnis. Jakarta :

Gramedia. Fowler, Martin. (2005). UML Destilled Edisi 3. Yogyakarta : Andi.

Gaol, Jimmy. (2008). Sistem Informasi Manajemen Pemahaman dan Aplikasi. Jakarta : Grasindo

Hartono, Jogiyanto. (2003). Analisis dan Desain Sistem Informasi. Yogyakarta: Andi Offset.

Hidayat, Rahmat. (2008). Cara Praktis Membangun Website Gratis. Jakarta

:Gramedia. Komarudin. (2008). Manajemen administrasi perkantoran, Yogyakarta :

Kanisius Munawar. (2005). Pemodelan Visual Dengan UML. Yogyakarta : Graha Ilmu. 
Nugroho, Adi. (2009). Rekayasa Perangkat Lunak Menggunakan UML dan Java.Yogyakarta: Andi.

(2010). Rekayasa Perangkat Lunak Berorientasi Object dengan metode USDP. Yogyakarta : Andi.

Nugroho, Bunafit. (2004). PHP dan MYSQL Dengan Editor Dreamweaver MX. Yogyakarta: Andi.

Raymond, Mc. Leod. (2001). Sistem Informasi Manajemen, Jakarta, PT. Prenhallindo.

Soeherman, Bonnie. (2008). Designing Information System. Jakarta. : Gramedia.

Solihat, A. (2009). Menggunakan Internet. Bandung: Anwar Press.

Sugiarti, Yuni. (2013). Analisis dan Perancangan Uml (Unified Modeling Language) Generated VB.6. Yogyakarta: Graha Ilmu.

Yakub. (2004). Pengantar Sistem Informasi. Yogyakarta: Graha Ilmu.

Yuhefizar. (2008). Database Management Menggunakan Microsoft access 2003. Jakarta : Grameida.

Zaki, Ali. (2008). 36 Menit Belajar PHP dan MySQl. Jakarta : Gramedia 